\title{
Human Cells, Tissues, and Cellular and Tissue-Based Products Storage
}

National Cancer Institute

\section{Source}

National Cancer Institute. Human Cells, Tissues, and Cellular and Tissue-Based Products

Storage. NCI Thesaurus. Code C133288.

Holding Human Cells, T issues, and Cellular and T issue-Based Products (HCT/Ps) for future processing and/or distribution. 